\title{
Folic Acid Deficiency in Congestive Heart Failure*
}

\author{
JEROME I. BRODY†, HENRY D. SOLTYS, AND HARRY F. ZINSSER \\ From the Department of Medicine, Graduate Hospital of the University of Pennsylvania, and the University \\ of Pennsylvania School of Medicine, Philadelphia, Pennsylvania, U.S.A.
}

The purpose of this report is to indicate that deficiency of folic acid occurs with notable frequency in patients with past or immediate congestive heart failure. The study described was stimulated by the clinical examination of two anaemic patients with heart disease whose bone-marrows showed morphological features consistent with a lack of this haematinic. There were several additional reasons, however, to think that a project organized to pursue this initial impression was potentially worth while. First, patients with heart disease and congestive failure are anorexic, eat sparingly, and receive sodium-restricted diets lacking foods in which folic acid is found (Herbert, 1962). In addition, many such patients have abnormalities of liver function (Richman, Delman, and Grob, 1961), related to chronic passive congestion, which leads to this organ's inability to store active metabolites of folic acid (Cherrick et al., 1965). Finally, gastrointestinal malabsorption (Valberg et al., 1965) associated with congestive failure could further contribute to folic acid deficiency in these patients.

\section{SubJECTS AND METHOdS}

Twelve patients, 8 women and 4 men, who ranged in age from 26 to 69 years, were admitted to the Clinical Research Center of the Graduate Hospital of the University of Pennsylvania in unselected sequence as they came under the surveillance of the authors. Their economic status was such as to make any dietary limitation the result of a medical rather than a financial imposition. Ten had rheumatic heart disease with varying valvular abnormalities, one patient had arteriosclerotic heart disease with a recent myocardial infarction, and one patient congenital pulmonary stenosis and a ventricular septal defect. Their relevant clinical data are given in Table I. Except for 2 patients (Cases 9 and 12), who were untreated, all others were receiving a form of digitalis and had previously taken or were getting some

Received March 17, 1969.

* Supported by a USPHS training grant and a USPHS Clinical Research Center grant.

† Recipient of a USPHS Career Development Award. type of diuretic at the time of the study. None had historical or clinically recognizable evidence of a primary blood dyscrasia. Splenomegaly had been present for 2 and 5 years in Cases 8 and 10, respectively, without additional symptoms or signs of an underlying disorder of a haematopoiesis. Enlargement of this organ, under the circumstances mentioned, probably represents a proliferative response (Jandl and Aster, 1967) to repeated episodes of heart failure and hepatic venous congestion. Case 1 had very large bleeding haemorrhoids which ultimately required surgical correction, and the second patient had clinical and radiological evidence of an intermittently active duodenal ulcer.

In order to define the lack of haematinics and the presence, type, and genesis of anaemia, the following studies were performed in the Clinical Center: complete blood count, including platelet and reticulocyte counts; bone-marrow aspiration and examination of the peripheral blood smear; Coombs test; serum iron (Peters et al., 1956) and total iron-binding capacity (Ramsay, 1957); serum folate* (Herbert and Zalusky, 1962) and vitamin $B_{12} \star$ (Lear et al., 1954) levels; serum bilirubin; bromsulfalein excretion; 25 g., 5-hour D-xylose excretion (Christiansen, Kirsner, and Ablaza, 1959); Schilling test (Schilling, 1953); red cell mass with ${ }^{51} \mathrm{Cr}$ (Gray and Frank, 1953); and red cell survival using the same isotope (Ebaugh, Emerson, and Ross, 1953) with scanning for selective splenic sequestration (Jandl and Aster, 1967). Since folic acid deficiency is acknowledged in a variety of benign and malignant conditions, such as pregnancy, cirrhosis, chronic infection, rheumatoid arthritis, cancer, and leukaemia, the inclusion of non-cardiacs as comparative controls in the present study seemed pointless. Rather, the protocol was designed specifically to determine whether deficiency of folate was associated with heart disease per se.

\section{RESULTS}

Absolute reticulocytosis was never detected in any patient, all total white blood cell and platelet counts were normal, and all Coombs tests were negative. Additional results are summarized in Table II. A total of 5 patients had anaemia.

\footnotetext{
* Using L. casei and E. gracilis, respectively.
} 
TABLE I

CLINICAL DATA ON STUDY PATIENTS

\begin{tabular}{|c|c|c|c|c|c|c|}
\hline \multicolumn{3}{|c|}{$\begin{array}{l}\text { Case No., age } \\
\text { (yr.), and sex }\end{array}$} & Type of heart disease & Diuretics & Hepatomegaly & Splenomegaly \\
\hline 1 & & $\mathbf{F}$ & Rheumatic heart disease; mitral steno- & $\begin{array}{l}\text { Chlorothiazide; mercaptomerin } \\
\text { sodium }\end{array}$ & $\begin{array}{l}2 \mathrm{~cm} \text {; ; congestive heart } \\
\text { failure }\end{array}$ & None \\
\hline $\begin{array}{l}2 \\
3\end{array}$ & $\begin{array}{l}46 \\
69\end{array}$ & $\begin{array}{l}\mathbf{F} \\
\mathbf{F}\end{array}$ & $\begin{array}{l}\text { Rheumatic heart disease; mitral stenosis } \\
\text { Rheumatic heart disease; mitral stenosis }\end{array}$ & $\begin{array}{l}\text { None } e^{\star} \\
\text { NH4Cl; acetazolamide }\end{array}$ & $\begin{array}{l}1 \mathrm{~cm} \text {. } \\
5 \mathrm{~cm} \text {; congestive heart } \\
\text { failure }\end{array}$ & $\begin{array}{l}\text { None } \\
\text { None }\end{array}$ \\
\hline 4 & 56 & $\mathbf{F}$ & $\begin{array}{l}\text { Rheumatic heart disease; mitral steno- } \\
\text { sis; tricuspid insufficiency }\end{array}$ & Mercaptomerin sodium & $\begin{array}{l}6 \mathrm{~cm} \text {.; congestive heart } \\
\text { failure }\end{array}$ & None \\
\hline 5 & 40 & $\mathbf{F}$ & Rheumatic heart disease; mitral stenosis & $\begin{array}{l}\text { Mercaptomerin sodium; etha- } \\
\text { crynic acid; aldactone }\end{array}$ & $\begin{array}{l}6 \mathrm{~cm} \text {; congestive heart } \\
\text { failure }\end{array}$ & None \\
\hline 6 & 54 & $\mathbf{M}$ & Arteriosclerotic heart disease & $\begin{array}{l}\text { NH4Cl; mercaptomerin } \\
\text { sodium }\end{array}$ & $\begin{array}{l}4 \mathrm{~cm} \text {; ; congestive heart } \\
\text { failure }\end{array}$ & None \\
\hline 7 & 41 & $\mathbf{F}$ & $\begin{array}{l}\text { Rheumatic heart disease; mitral stenosis } \\
\text { and insufficiency; aortic stenosis and } \\
\text { insufficiency }\end{array}$ & Mercaptomerin sodium & $\begin{array}{l}3 \mathrm{~cm} \text {; congestive heart } \\
\text { failure }\end{array}$ & None \\
\hline 8 & 29 & $\mathbf{M}$ & $\begin{array}{l}\text { Rheumatic heart disease; mitral steno- } \\
\text { sis; aortic insufficiency }\end{array}$ & $\mathrm{NH} 4 \mathrm{Cl}$; acetazolamide & $2 \mathrm{~cm}$. & $1 \mathrm{~cm}$. \\
\hline 9 & 26 & $\mathbf{M}$ & $\begin{array}{l}\text { Congenital heart disease; pulmonary } \\
\text { stenosis; ventricular septal defect }\end{array}$ & None & None & None \\
\hline $\begin{array}{l}10 \\
11\end{array}$ & $\begin{array}{l}55 \\
38\end{array}$ & $\begin{array}{l}\mathrm{F} \\
\mathbf{M}\end{array}$ & $\begin{array}{l}\text { Rheumatic heart disease; mitral stenosis } \\
\text { Rheumatic heart disease; aortic stenosis } \\
\text { and insufficiency }\end{array}$ & $\begin{array}{l}\text { Mercaptomerin sodium } \\
\text { Mercaptomerin sodium }\end{array}$ & $\begin{array}{l}2 \mathrm{~cm} . \\
2 \mathrm{~cm} \text {; congestive heart } \\
\text { failure }\end{array}$ & $\begin{array}{l}5 \mathrm{~cm} . \\
\text { None }\end{array}$ \\
\hline 12 & 49 & $\mathbf{F}$ & Rheumatic heart disease; mitral stenosis & None & None & None \\
\hline
\end{tabular}

^ Case 2 had previously received mercaptomerin sodium.

Three (Cases 1, 2, and 7) were overtly anaemic as shown by the venous haemoglobin and haematocrit; ${ }^{51} \mathrm{Cr}$ isotope study was confirmatory. The other 2 patients, however, had a normal haemoglobin and haematocrit, but the actual red cell mass was low (Cases 6 and 10). The explanation for the spuriously normal and misleading peripheral blood values most probably is the acknowledged haemoconcentration produced by diuretics.

The only completely normal peripheral blood smears were seen in 5 of the 7 non-anaemic patients (Cases 3, 5, 8, 9, and 12). The peripheral blood of the remaining 2 patients without anaemia and those in whom the red cell mass was low all showed morphological abnormalities of the erythrocytes and/or leucocytes. Evidence of combined iron deficiency, as hypochromia, and suspected megaloblastosis, as macrocytosis or hyperlobulated neutrophils (macropolycytes), was seen in 3 instances (Cases 1, 2, and 4) though the last patient was not anaemic. The remaining 4 patients had smears consistent with folic acid or vitamin $\mathrm{B}_{12}$ deficiency (Cases 6, 7, 10, and 11).

Except for 2 patients (Cases 9 and 12), all the

TABLE

SUMMARY OF

\begin{tabular}{|c|c|c|c|c|}
\hline Case & $\stackrel{\mathrm{Hb}}{(\mathrm{g} . / 100 \mathrm{ml} .)}$ & $\begin{array}{c}\text { Haematocrit } \\
(\%)\end{array}$ & Peripheral smear & Bone-marrow \\
\hline $\begin{array}{r}2 \\
3 \\
4 \\
5 \\
6 \\
7 \\
8 \\
9 \\
10 \\
11 \\
12\end{array}$ & \begin{tabular}{r|}
$8 \cdot 1$ \\
$8 \cdot 0$ \\
$13 \cdot 0$ \\
$13 \cdot 9$ \\
$14 \cdot 6$ \\
$15 \cdot 2$ \\
$10 \cdot 2$ \\
$15 \cdot 5$ \\
$15 \cdot 7$ \\
$12 \cdot 0$ \\
$13 \cdot 6$ \\
$13 \cdot 9$
\end{tabular} & $\begin{array}{l}31 \\
26 \\
40 \\
42 \\
43 \\
43 \\
30 \\
48 \\
49 \\
37 \\
43 \\
41\end{array}$ & $\begin{array}{l}\text { Hypochromic; macrocytic } \\
\text { Hypochromic; macrocytic } \\
\text { Normocytic; normochromic } \\
\text { Hypochromic; macrocytic; macropolycyte } \\
\text { Normocytic } \\
\text { Macrocytic } \\
\text { Macrocytic } \\
\text { Normochromic; normocytic } \\
\text { Normochromic; normocytic } \\
\text { Macrocytic } \\
\text { Macrocytic; macropolycyte } \\
\text { Normocytic; normochromic }\end{array}$ & 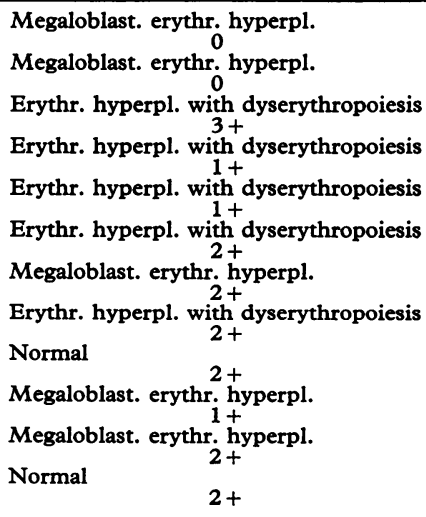 \\
\hline
\end{tabular}

+ signs refer to haemosiderin graded on a basis of 0 to 4 (normal $1+$ to $2+$ ). 


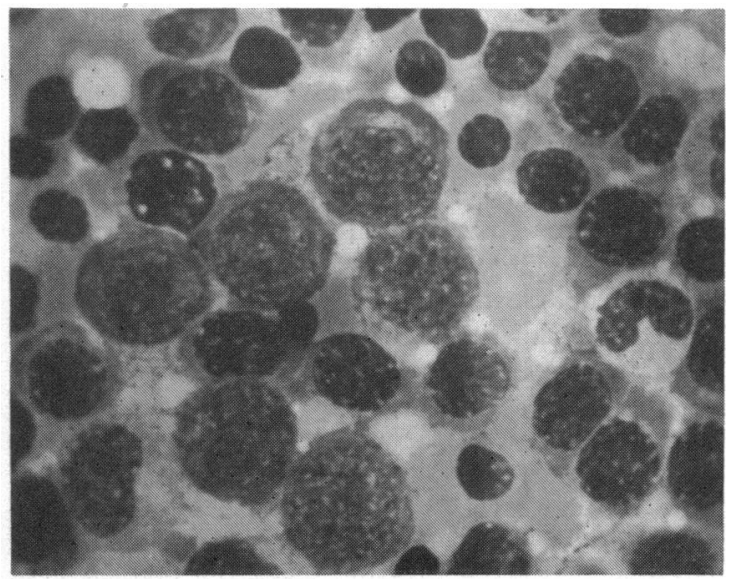

FIG.-The characteristic appearance of the bone-marrow in the study patients showing erythroid hyperplasia with dyserythropoiesis. $(\times 1000$.

bone-marrows, even those from patients who had as yet not become anaemic, showed erythroid hyperplasia (Fig.). They were either overtly megaloblastic or the red cell precursors showed analogous, more subtle changes in the form of dyssynergic development of nucleus and cytoplasm (dyserythropoiesis). In 2 instances (Cases 1 and 2), bonemarrow iron stores were diminished, and, predictably, the serum iron and percentage iron saturation also were low.

In 4 patients, the serum bilirubin and the brom- sulfalein excretion, separately or in combination, were mildly or moderately abnormal. The bromsulfalein alone was raised in Cases 6,10, and 11, and both the serum bilirubin and bromsulfalein retention were increased in Case 7. Xylose excretion tests were performed on 11 patients; abnormally low values were detected in 7 . In contrast, the 10 Schilling tests done were all within normal limits. The ${ }^{51} \mathrm{Cr}$ red cell survival was shortened in 4 of 10 instances (Cases 2, 6, 7, and 10) in which this test was done. Haemolysis was never reflected by reticulocytosis, an observation not without precedent (Chapman, 1968), but was mirrored by the mild hyperbilirubinaemia of Case 7 with abnormal bromsulfalein excretion. Selective splenic sequestration was not present in any of the 10 patients on whom red cell survivals were performed.

Impressively, serum folate levels were below 4 ng./ml. in every patient except for 2 (Case 9, with congenital heart disease, and Case 12 with rheumatic heart disease and mitral stenosis), both of whom had never been in congestive failure and had never received digitalis or diuretics. These patients, quite without intention, ultimately served as internal controls in this investigation. In contrast, vitamin $\mathrm{B}_{12}$ concentrations were never depressed in any of the patients studied.

\section{Discussion}

The consistently low serum folate in all patients with immediate or past congestive heart failure, and the contrary absence of this abnormality in the

II

RESULTS

\begin{tabular}{|c|c|c|c|c|c|c|c|c|c|}
\hline $\begin{array}{c}\mathrm{Fe} \\
(70-150)^{\star}\end{array}$ & $\begin{array}{c}\text { TIBC } \\
(\mu \mathrm{g} .) \\
(230-415)\end{array}$ & $\begin{array}{c}\text { Folate } \\
(\text { ng./ml. }) \\
(4-18)\end{array}$ & $\begin{array}{c}\mathbf{B}_{12} \\
(\mathrm{pg} . / \mathrm{ml} .) \\
(150-1200)\end{array}$ & $\begin{array}{c}\text { Bilirubin } \\
(\mathrm{mg} \cdot / 100 \mathrm{ml} .) \\
(0 \cdot 2 / 1 \cdot 2)\end{array}$ & $\begin{array}{c}\text { Brom- } \\
\text { sulfalein } \\
(\%) \\
(<5)\end{array}$ & $\begin{array}{c}\text { Xylose } \\
(\mathbf{G} / 5 \mathrm{hr} .) \\
(>5)\end{array}$ & $\begin{array}{c}\text { Schilling } \\
(\%) \\
(>10)\end{array}$ & $\begin{array}{l}\text { R. mass } \\
(\mathrm{ml} . / \mathbf{k g} .) \\
(28 \pm 4)\end{array}$ & $\begin{array}{c}\mathrm{T} / 2 \\
\text { days } \\
(30 \pm 5)\end{array}$ \\
\hline 48 & 328 & 1.8 & 698 & $0 \cdot 3 / 0 \cdot 8$ & - & - & 22 & $20 \cdot 2$ & - \\
\hline 40 & 332 & $1 \cdot 2$ & 480 & $0 \cdot 2 / 0 \cdot 8$ & 5 & $4 \cdot 7$ & 20 & $19 \cdot 0$ & $19 \cdot 5$ \\
\hline 77 & 268 & $1 \cdot 3$ & 161 & $0 \cdot 1 / 0 \cdot 7$ & 2 & $1 \cdot 4$ & - & $24 \cdot 3$ & $\mathbf{N}$ \\
\hline 95 & 280 & 3.0 & 170 & $0 \cdot 2 / 0 \cdot 6$ & 3 & $3 \cdot 2$ & 24 & $28 \cdot 2$ & $\mathbf{N}$ \\
\hline 76 & 256 & $<1$ & 592 & $0.2 / 0.7$ & 4 & $7 \cdot 8$ & - & $28 \cdot 8$ & - \\
\hline 98 & 263 & 3.8 & 362 & $0 \cdot 2 / 0 \cdot 8$ & 8 & 4.0 & 13 & $20 \cdot 4$ & 18 \\
\hline 79 & 278 & $2 \cdot 4$ & 1120 & $0.9 / 1.9$ & 13 & 7.9 & 12 & $15 \cdot 6$ & $16 \cdot 2$ \\
\hline 112 & 396 & $1 \cdot 8$ & 420 & $0 \cdot 1 / 0 \cdot 8$ & 1 & $2 \cdot 4$ & 17 & $30 \cdot 3$ & $\mathbf{N}$ \\
\hline 110 & 288 & $8 \cdot 2$ & 282 & $0 \cdot 2 / 1 \cdot 2$ & 5 & $6 \cdot 2$ & 18 & $30 \cdot 7$ & $\mathrm{~N}$ \\
\hline 148 & 310 & $1 \cdot 4$ & 1180 & $0.2 / 0.6$ & 8 & $4 \cdot 2$ & 25 & $20 \cdot 3$ & $14 \cdot 5$ \\
\hline 100 & 240 & $2 \cdot 3$ & 172 & $0 \cdot 4 / 1 \cdot 0$ & 9 & 3.9 & 23 & 28.5 & $\mathbf{N}$ \\
\hline 88 & 220 & $7 \cdot 5$ & 210 & $0 \cdot 3 / 1 \cdot 1$ & 4 & $5 \cdot 8$ & 15 & $25 \cdot 2$ & $\mathbf{N}$ \\
\hline
\end{tabular}

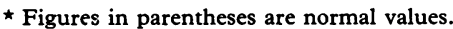


patients with unquestionable heart disease, yet who never required treatment (Cases 9 and 12, Tables I and II) all lead to the tempered conclusion that the manifestations and therapy of progressive congestive failure probably influence the factors that regulate blood folic acid concentration.

Abnormal D-xylose excretion ${ }^{\star}$ observed in 7 instances makes it logical to assume that the tissue anoxia and gastro-intestinal congestion associated with heart failure distort the physiological function of at least certain portions of the small intestine. The acknowledged absorption of both xylose and folic acid in the jejunum, the latter probably by active transport (Hepner, 1969), and the normal Schilling tests and serum vitamin $B_{12}$ levels in the patients studied, all infer that malabsorption, which may be selective, appears to be an important mechanism leading to the observed folate deficiency. Iron deficiency (Cases 1, 2, and 4) is known to augment this absorptive defect (Velez et al., 1966). Diuretics, which theoretically affect gastrointestinal as well as renal epithelium, may have an additional adverse influence (Hagedorn, Kaplan, and Hulet, 1965; Binder et al., 1966). It is likewise reasonable to consider that, since folic acid is filtered at the glomerulus and is partially absorbed by the renal tubules (Goresky, Watanabe, and Johns, 1963), prolonged diuresis also could contribute to folic acid deficiency by increasing excretion of this material.

The presence of erythroid hyperplasia and bonemarrow megaloblastosis in the congestive heart failure patients studied, and decreased red cell survival in certain instances ( 4 of 8 patients), is evidence that folic acid requirements in these patients are raised and are not being satisfied (Chanarin, Dacie, and Mollin, 1959; Jandl and Greenberg, 1959). This conclusion is supported by the high urinary excretion of formiminoglutamic acid described in a study analogous to the present investigation (Daly and Rose, 1966). Excessive haemolysis, previously detected in a significant percentage of patients with heart disease (Jorgensen, Zimmerman, and Wang, 1967), creates an unsatisfied, increased need for folic acid, while folic acid deficiency, occurring because of decreased intake, poor absorption, or increased excretion, may lead to megaloblastic ineffective erythropoiesis (Jandl and Greenberg, 1959).

The clinical importance of folic acid deficiency in patients with congestive heart failure, aside from this agent's obvious role in haematopoiesis, remains speculative for the moment. Hypothetically, and

* The authors recognize that xylose excretion may be abnormal in renal disease. Though some of these patients had mild prerenal azotaemia, secondary to congestive failure, their creatinine values and urinary outputs were well within normal limits. unproved (Braunwald, Ross, and Sonnenblick, 1967), the lack of folic acid may lead to a loss of myocardial high energy phosphate stores by failing to support adequate synthesis of purine bases. This abnormality may take the form of decreased concentrations of adenosine triphosphate or an adenosine triphosphatase, necessary for activation of myocardial contractile filaments (Fox and Reed, 1966; Alpert and Gordon, 1962). Whereas there is no direct experimental evidence from this study that the diminution of folic acid is felt beyond the haematopoietic system, the presence of bone-marrow megaloblastosis, even without demonstrable anaemia, indicates that folic acid deficiency is expressed on a cellular level. Therefore, a biochemical disturbance of this type could, under appropriate circumstances, theoretically make the management of congestive heart failure more difficult and possibly promote a refractory state. At the moment, folic acid should be given as a haematinic to patients with heart disease and overt anaemia, as was done with patients in this study who responded appropriately. Its use as an adjunct in the treatment of heart failure, per se, or before a diagnosis of anaemia is made, remains an unresolved problem for future investigation.

\section{SUMMARY}

Of a group of 12 patients with cardiovascular disease, 10 with rheumatic or arteriosclerotic heart disease and requiring digitalis and diuretics had low serum folate levels measured by bioassay. The exceptions were a patient with pulmonary stenosis and a ventricular septal defect and one with rheumatic heart disease and mitral stenosis, both of whom had never required any form of treatment. Though only 5 of the 10 folic acid deficient patients were anaemic at the time of the study, as shown by the peripheral blood haemoglobin, and haematocrit, or ${ }^{51} \mathrm{Cr}$ red cell mass, all had megaloblastic bonemarrows. These results indicate that folic acid deficiency occurs with notable frequency in patients with congestive heart failure. The severity of the heart disease and the measures required for its management most probably influence, in an adverse manner, the factors that normally regulate folic acid requirements, intake, and absorption, and ultimately lead to a lack of this haematinic.

\section{REFERENCES}

Alpert, N. R., and Gordon, M. S. (1962). Myofibrillar adenosine triphosphatase activity in congestive heart failure. Amer. F. Physiol., $202,940$.

Binder, H. J., Katz, L. A., Spencer, R. P., and Spiro, H. M. (1966). The effect of inhibitors of renal transport on the small intestine. $\mathcal{F}$. clin. Invest., 45, 1854.

Braunwald, E., Ross, J., and Sonnenblick, E. H. (1967). 
Mechanisms of the normal and failing heart. New Engl. F. Med., 277, 962.

Chanarin, I., Dacie, J. V., and Mollin, D. L. (1959). Folicacid deficiency in haemolytic anemia. Brit. F. Haemat., 5, 245.

Chapman, R. G. (1968). Red cell life span after splenectomy in hereditary spherocytosis. $\mathcal{F}$. clin. Invest., 47, 2263.

Cherrick, G. R., Baker, H., Frank, O., and Leevy, C. M. (1965). Observations on hepatic avidity for folate in Laennec's cirrhosis. f. Lab. clin. Med., 66, 446.

Christiansen, P. A., Kirsner, J. B., and Ablaza, J. (1959). $\mathrm{D}$-xylose and its use in the diagnosis of malabsorptive states. Amer. F. Med., 27, 443.

Daly, J. J., and Rose, D. P. (1966). Excretion of urocanic acid following oral histidine in heart failure. Brit. Heart f., 28, 698.

Ebaugh, F. G., Jr., Emerson, C. P., and Ross, J. F. (1953). The use of radioactive chromium 51 as an erythrocyte tagging agent for the determination of red cell survival in vivo. $\mathcal{F}$. clin. Invest., 32, 1260.

Fox, A. C., and Reed, G. E. (1966). Exchanges of nucleotide phosphates in normal and in failing canine hearts. Amer. F. Physiol., 210, 1383.

Goresky, C. A., Watanabe, H., and Johns, D. G. (1963). The renal excretion of folic acid. $\mathfrak{F}$. clin. Invest., 42, 1841.

Gray, S. J., and Frank, H. (1953). The simultaneous determination of red cell mass and plasma volume in man with radioactive sodium chromate and chromic chloride. F. clin. Invest., 32, 1000.

Hagedorn, C. W., Kaplan, A. A., and Hulet, W. H. (1965). Prolonged administration of ethacrynic acid in patients with chronic renal disease. New Engl. f. Med., 272, 1152.

Hepner, G. W. (1969). The absorption of pteroylglutamic (folic) acid in rats. Brit. F. Haemat., 16, 241.

Herbert, V. (1962). The diagnosis and treatment of folic acid deficiency. Med. Clin. N. Amer., 46, 1365.

$\longrightarrow$, and Zalusky, R. (1962). Interrelations of vitamin $\mathbf{B}_{12}$ and folic acid metabolism: folic acid clearance studies. F. clin. Invest., 41, 1263.

Jandl, J. H., and Aster, R. H. (1967). Increased splenic pooling and the pathogenesis of hypersplenism. Amer. f. med. Sci., 253, 383.
Jandl, J. H., and Greenberg, M. S. (1959). Bone-marrow failure due to relative nutritional deficiency in Cooley's hemolytic anemia: painful "erythropoietic crisis" in response to folic acid. New Engl. F. Med., 260, 461.

Jorgensen, C. R., Zimmerman, T. S., and Wang, Y. (1967). Serum lactate dehydrogenase elevation in ambulatory cardiac patients. Evidence for chronic hemolysis. Circulation, 35, 79.

Lear, A. A., Harris, J. W., Castle, W. B., and Fleming, E. M. (1954). The serum vitamin $B_{12}$ concentration in pernicious anemia. f. Lab. clin. Med., 44, 715.

Peters, T., Giovanniello, T. J., Apt, L., and Ross, J. F. (1956). A simple improved method for the determination of serum iron. f. Lab. clin. Med., 48, 280.

Ramsay, W. N. M. (1957). The determination of the total iron-binding capacity of serum. Clin. chim. Acta, 2, 221.

Richman, S. M., Delman, A. J., and Grob, D. (1961). Alterations in indices of liver function in congestive heart failure with particular reference to serum enzymes. Amer. F. Med., 30, 211.

Schilling, R. F. (1953). Intrinsic factor studies. II. The effect of gastric juice on the urinary excretion of radioactivity after the oral administration of radioactive vita$\min \mathrm{B}_{12}$. F. Lab. clin. Med., 42, 860.

Valberg, L. S., Corbett, W. E. N., McCorriston, J. R., and Parker, J. O. (1965). Excessive loss of plasma protein into the gastrointestinal tract associated with primary myocardial disease. Amer. F. Med., 39, 668.

Velez, H., Restrepo, A., Vitale, J. J., and Hellerstein, E. E. (1966). Folic acid deficiency secondary to iron deficiency in man. Remission with iron therapy and a diet low in folic acid. Amer. F. clin. Nutr., 19, 27.

\section{ADDENDUM}

While this paper was in review another laboratory (Hyde and Loehry, 1968) also pointed out that folic acid malabsorption occurred in congestive heart failure.

\section{REFERENCE}

Hyde, R. D., and Loehry, C. A. E. H. (1968). Folic acid malabsorption in cardiac failure. Gut, 9, 717 . 